\title{
Иммунитеты высших должностных лиц и их уголовное преследование за международные преступления
}

Русинова B.H.*

На пути осуществления уголовного преследования таких высокопоставленных лиц, как глава государства, глава правительства или министр иностранных дел, подозреваемых в совершении преступлений против человечности, геноцида, военных преступлений или преступления агрессии, неизбежно возникает юридическое препятствие - институт иммунитетов. Иммунитет как изьятие из административной, уголовной и гражданской юрисдикции государства предоставляется таким лицам как по национальному, так и по международному праву. Но положение этих лиц в своих государствах делает их практически недосягаемыми для национального правосудия. Это обуславливает важность уголовного преследования, осуществляемого международными уголовными судами и национальными судами, которые, действуя на основании экстерриториальных принципов, могут привлекать к ответственности иностранцев. Именно здесь и возникает конфликт между принципом индивидуальной уголовной ответственности за совершение преступлений по общему международному праву и международными иммунитетами высокопоставленных должностных лиц государства.

Иммунитетом от уголовной юрисдикции в иностранном государстве международное право наделяет глав государств, глав правительств, а также министров иностранных дел. Они в качестве «центральных органов внешних сношений» ${ }^{1}$ пользуются иммунитетом на основе международного обычая² ${ }^{2}$ Предоставление иммунитета этим высокопоставленным должностным лицам направлено на обеспечение эффективного осуществления государственных функций и базируется на принципе суверенного равенства государств и принципе невмеша-

\footnotetext{
"Русинова B.H. - LL.M. (Геттинген, Германия), аспирантка Института государства и права РАН.

${ }^{1}$ Курсмеждународного права. В 7 т. Т. 4. Отрасли международного права. М., 1990. С. 98. ${ }^{2}$ Case Concerning the Arrest Warrant of 11 April 2000 (Democratic Republic Congo v. Belgium). International Court of Justice. Judgment of 14 February 2002. P. 19. Para. 53 // ILM. 2002. № 41. (Далее: Arrest Warrant-Case. Judgment).
} 
тельства во внутренние дела. Высшим должностным лицам государства по международному праву предоставлен иммунитет ratione personae (персоналыный) и иммунитет ratione materiae (материалыый). При этом иммунитет ratione materiae защицает глав государств и других высокопоставленных лиц от уголовного преследования за деяния, которые они совершили в официальном качестве в течение срока своих полномочий; иммунитет ratione personae имеет процессуальную природу и налагает запрет на любое уголовное преследование в то время, когда лицо занимает соответствующую должность ${ }^{3}$.

В литературе можно встретить утверждения о том, что современное международное право не признает международного иммунитета высокопоставленных должностных лищ государства в случае, если они подозреваются или обвиняются в совершении преступлений по общему международному праву4 ${ }^{4}$. Насколько справедливо такое утверждение в отношении глав государств, глав правительств и министров иностранных дел? Для того чтобы ответить на этот вопрос, необходимо исследовать, каким образом соотносятся индивидуальная уголовная ответственность и международные иммунитеты таких лиц и в какой степени действие международных иммунитетов препятствует привлечению виновных в совершении международных преступлений к уголовной ответственности, если вообще препятствует. Представляется логичным исследовать, что представляет собой институт иммунитетов руководителей государства на современном этапе развития международного права, отделив друг от друга международный и национальный уровни преследования индивидов за совершение преступлений по общему международному праву из-за различий самой сущности уголовного преследования на этих уровнях.

\section{I. Преследование международных преступлений международными судами}

\section{1. Нюрнбергский и Токийские процессы}

Поворотным моментом в истории доктрины абсолютного иммунитета глав государств стало преследование главных военных преступников после второй мировой войны. В статье 7 Устава Международ-

${ }^{3}$ CM.: Princeton Project on Universal Jurisdiction: Princeton Principles on Universal Jurisdiction. Commentary. P. 32, http://www.princeton.edu/-lapa/unive jur.pdf (Далеесокр.: Princeton Principles. Commentary).

${ }^{4}$ См.: Иногамова-Хегай Л.В. Международное уголовное право. М., 2003. С. 106. 
ного воснного трибунала для суда и наказания главных военных преступников европейских стран оси было записано, что «должностное положение подсудимых, их положение в качестве глав государства или ответственных чиновников различных правительственных ведомств не должно рассматриваться как основание к освобождению от ответственности или смягчению наказания» ${ }^{5}$. В приговоре Нюрнбергского трибунала подчеркивалось: «...принщип международного права, который при определенных обстоятельствах защищает представителя государства, не может быть применен к действиям, которые осуждаготся как преступные согласно международному праву. Исполнители этих действий не могут прикрываться своим должностным положением, чтобы избежать наказания в надтежащем порядке»б.

В рамках Нюрнбергского процесса перед судом предстал адмирал Карл Дениц, который стал главой государства после смерти Гитлера, a во время Токийского процесса были привлечены к ответственности четыре бывших премьер-министра (Тодзио, Харанума, Хирото, Койсо) и одиннадцать бывших министров. Хотя нельзя не отметить, что положение о нераспространении иммунитетов на высших должностных лиц государства в случае совершения ими международных преступлений было не в полной мере реализовано на практике: в частности, так и не был привлечен к уголовной ответственности император Японии - Хирохито?

\section{2. Международные ad hoc трибуналы}

После Нюрнберрга и Токио развитие провозглашенного исключения из правила об абсолютном иммунитете представителей государств было продолжено только в 1993 г. с учреждением международных ad hoc трибуналов по бывшей Югославии и Руанде. В уставах этих трибуналов закреплено, что «должностное положение обвиняемого в качестве главы государства или правительства или ответственного чиновника не освобождает это лицо от уголовной ответственности и не является основанием Для смягчения наказания» ${ }^{8}$.

${ }^{5}$ Устав международного военного трибунала для суда и наказания главных военных преступников европейских стран оси от 8 августа 1945 г. // Действующее международноеправо. В 3 т. Т. 3. М., 1999. С. 763.

${ }^{6}$ Приговор Международного военного трибунала//Нюрнбергский процесс. Сборник материалов. Т. 2. М., 1954. С. 992.

${ }^{7}$ O'Neill K.C. A New Customary Law of Head of State Immunity?: Hirohito and Pinochet // Stanford Journal of International Law. 2002. № 38. P. 298-305. 
Некоторые комментаторы сразу же поспешили сделать вывод о том, что вышеприведенная формулировка означает, что привлечению к уголовной ответственности не препятствует материальный иммунитет, при том что персональный иммунитет сохраняет свое действие. Но справедливость этого заключения была опровергнута самим Международным трибуналом по бывшей Югославии, когда в 2000 г. было подписано обвинительное заключение в отношении Слободана Милошевича, который в то время еще занимал пост президента ${ }^{9}$. Многие гристы-международники пришли к выводу, что это был первый прецедент, когда уголовное преследование началось вопреки действию иммунитетов по международному праву ${ }^{10}$. Однако Слободан Милошевич так и не стал первым в истории действующим главой государства, который был привлечен к уголовной ответственности за международные преступления вопреки действию международного иммунитета ratione personae: Милошевич был арестован и передан Югославскому трибуналу уже после того, как покинул пост президента.

Международный трибунал по Руанде осудил бывшего премьер-министра страны - Жана Камбанду, но в отличие от дела Милошевича обвинительное заключение в отношении Камбанды было вынесено в 1997 г. ${ }^{11}$, т.е. когда он уже не пользовался персональным иммунитетом. Таким образом, процесс над Милошевичем демонстрирует признание приоритета преследования преступлений по общему международному праву над институтом международных иммунитетов бывших глав государств. Однако нельзя не отметить, что в силе этого прецедента заставляет усомниться тот способ, которым С. Милошевич был доставлен в Гаагу. Тем не менее можно утверждать, что в уставах международных $a d$ hoc трибуналов по бывшей Югославии и Руанде был зафиксирован отказ от материального и процессуального иммунитета высокопоставленньх должностных лиц.

\footnotetext{
8 Часть 2 ст. 7 Устава Международного трибунала по бывшей Югославии; часть 2 ст. 6 Устава Международного уголовного трибунала по Руанде // Действующее международноеправо. М., 1999. В 3 т. Т. 1.С. 748, 761.

${ }^{9}$ CM.: Magliveras K.D. The Interplay Between the Transfer of Slobodan Milosevic to the ICTY and Yugoslav Constitutional Law//European Journal of International Law. 2002. P. 661-677.

${ }^{10}$ Princeton Principles. Commentary. P. 52.

${ }^{11}$ International Criminal Tribunal for Rwanda, Prosecutor vs. Jean Kambanda. Indictment of 16 October 1997. ICTR-97-23-DP. Para. 1-2, http:/www.ictr.org/ENGLISH/cases/ Kambanda/indictment/index.pdf.
} 


\section{3. Международный уголовный суд}

В статье 27 Римского статута, учредившего Международный уголовный суд ${ }^{12}$, прямо закреплено, что «должностное положение... ни в коем случае не освобождает лицо от уголовной ответственности...», «иммунитеты или специальные процессуальные нормы, которые могут быть связаны с должностным положением лица, будь то согласно национальному или международному праву, не должны препятствовать осуществлению судом его юрисдикции в отношении такого лица». Эта статья Римского статута должна рассматриваться в совокупности с нормами, регулирующими взаимодействие государств- участников статута и Межлународного уголовного суда, в частности, в совокупности с ч. 1 ст. 98 статута, по которой «суд не может обращаться с просьбой о предоставлении в распоряжение или с просьбой о помощи, которая требовала бы от запрашиваемого государства действий, противоречащих его обязательствам по международному праву в отношении государственного или дипломатического иммунитета лица или имущества другого государства, до тех пор, пока суд не заручится сотрудничеством этого другого государства в вопросе отказа от иммунитета». Следовательно, Международный уголовный суд правомочен привлекать к уголовной ответственности высших должностных лиц государств - участников Римского статута, и только в том случае, если обвиняемым является наделенное международным иммунитетом должностное лицо «третьего государства», суд обязан сначала заручиться согласием этого государства.

Таким образом, в международном праве утвердился принцип, по которому при осуществлении уголовного преследования международными уголовными судами действие иммунитетов высших должностных лиц государства не препятствует привлечению их к индивидуальной ответственности за международные преступления.

\section{II. Преследование международных преступлений}

\section{национальными судами}

На уголовное преследование высокопоставленных должностных лиц, осуществляемое национальными судами других государств, огромное влияние оказывает политика, а не право, что делает такое преследование редкостью, но при этом не делает его невозможным.

${ }^{12}$ Римский статут Международного уголовного суда от 17 июля 1998 г. // UN Doc. A/ CONF.183/9. 
Как справедливо отмечает И.И. Лукашук, «проблема индивидуальной уголовной ответственности руководителей государств представляется одной из важнейших в обеспечении эффективности международного права и вместе с тем одной из сложнейших, поскольку решения об этом принимаются руководителями государств» ${ }^{13}$. Но даже абстрагируясь от политической подоплеки таких процессов, с правовой точки зрения уголовное преследование высокопоставленных должностных лиц государств иностранными судами сильно затруднено действием международных иммунитетов. Убедительным доказательством тому служит вынесенное в 2002 г. решение Международного суда ООН по делу об ордере на арест.

\section{1. Решение Международного суда ООН по делу об ордере на арест}

11 апреля 2000 г. бельгийский судья выдал международный ордер на арест in absentia в отношении тогда еще действующего министра иностранных дел Конго А.Й. Ндомбаси, который обвинялся в совершении международных преступлений. 17 октября 2000 г. Конго направило в Международный суд заявление, в котором обвинило Бельгию в нарушении международного права в связи с тем, что выдавая ордер на арест министра, Бельгия посягнула на иммунитет должностного лица Конго, а также неправомерно инициировала преследование in absentia на основании принципа универсальной юрисдикции ${ }^{14}$.

Рассматривая это дело, Международный суд пришел к выводу о том, что действующий министр иностранных дел обладает иммунитетом от уголовного преследования иностранными судами и не может быть привлечен к уголовной ответственности, даже несмотря на то, что он обвиняется в совершении международных преступлений: таких, как военные преступления или преступления против человечности ${ }^{15}$. Это решение суда подверглось острой критике не только в литературе ${ }^{16}$, но ${ }^{13}$ Лукашук И.И. Международное право. Общая часть: Учебник. М., 2001. С. 74.

${ }^{14}$ Arrest Warrant-Case. Judgment. Para. 45.

${ }^{15}$ Ibid. Para. 58.

${ }^{16}$ Sands $P h$. International Law Transformed? From Pinochet to Congo...? // Leiden Journal of International Law. 2003. Vol. 16. ${ }^{1}$ 1. P. 49; Kress C. Der Internationale Strafgerichtshof im Spannungsfeld von Völkerrecht und Immunitätsschutz. Besprechung von IGH Urteil vom 14.02.2002 (Demokratische Republik Kongo vs. Belgien) // Goltdammer's Archiv für Strafrecht. 2003. S. 33 f.; Wirth S. Immunity for Core Crimes? The ICJ's Judgment in the Congo vs. Belgium Case//European Journal of International Law. 2002. Vol. 13. ${ }^{1}$ 4. Đ. 888 f.; Gries T. Der aktuelle Fall: Der lange Arm des nationalen Richters: Demokratische Republik Kongo vs. Königreich Belgien // Humanitäres Völkerrecht. 2001. S. 25. 
и со стороны ряда судей этого же суда ${ }^{17}$. Отметим, что в самом решении Международного суда не содержигся дегального анализа аргументов, которые приводили стороны в обоснование своей позиции, а приведен лишь ряд общих выводов в отношении этих аргументов. В частности, суд указывает на то, что исследование практики государств, включая национальное законодательство и решения верховных судов некоторых государств, не позволяет вывести правило об отсутствии международного иммунитета у действующих глав государств. Кроме того, из посвященных иммунитетам или должностному положению предписаний уставов международных судов, равно как и из их решений нельзя вывести правило о том, что иммунитеты высокопоставленных должностных лиц не действуют в случае преследования таких лиц национальными судами ${ }^{18}$.

Придавая своим выводам завершенную форму, Международный суд не ограничился решением вопроса об иммунитете действуюшего министра иностранных дел и решил обобщить случаи, когда иммунитет высокопоставленного должностного лица все же не препятствует осуществлениюо уголовного преследования. Так, суд указал, что суды иностранных государств могут привлечь таких лицк уголовной ответственности, если государство, которое они представляют, решит лишить их иммунитета, либо, если лицо покинет соответствуюций пост, его можно будет привлечь за «Деяния, совершенные до или после нахождения в соответствующей должности, равно как и за деяния, совершенные в частном качестве в течение срока полномочий ${ }^{19}$. Тем самым Международный суд высказался в подлержку действия на националыном уровне иммунитета высокопоставленных должностных лиц даже в случае обвинения их в совершении преступлений по общему международному праву. Причем, по мнению суда, уголовному преследованию препятствуют не только иммунитет ratione personae, которым наделены действующие высокопоставленные должностные лица государства, но и иммунитет ratione materiae бывших руководителей государства за действия, совершенные в официальном качестве. Однако детальное исследование как доводов сторон, так и других обстоятельств, которые было бы логично рассмотреть в связи с данным вопросом, позволяет обоснованно не согласиться с мнением уважаемого суда.

${ }^{17}$ CM.: Arrest Warrant-Case. Dissenting Opinion of Judge van den Wyngaert. Paras. 24-28; Dissenting Opinion of Judge Al-Khasawneh. Paras. 5-7.

${ }^{18}$ Arrest Warrant-Case. Judgment. Para. 58.

${ }^{19}$ Ibid. Para. 61 . 


\section{2. Соотношение института международных иммунитетов и уго-}

ловной ответственности за совершение преступлений по общему международному праву

При исследовании данной проблемы необходимо в первую очередь обратиться к вопросу о сущности преступлений по общему международному праву. Можно считать уже общепризнанным положение о том, что подобные преступления регулируются непосредственно международным правом и обладают особой природой. Как справедливо отметил в решении Палаты лордов по делу Пиночета лорд Вилкинсон: «Как может соответствовать международному праву официальное полномочие делать то, что само международное право запрещает и криминализует?» ${ }^{20}$, причем соответствующие запреты международного права носят императивный характер, представляя собой нормы jus cogens, - добавим мы.

Получалось, что решение Международного суда по делу об ордере на арест практически игнорирует все предшествующее развитие международного уголовного права, т.к. положение о том, что индивид не может «спрятаться» за государство, составляет саму сущность принципа индивидуальной уголовной ответственности ${ }^{21}$. Исторически утверждение в международном праве принципа индивидуальной уголовной ответственности за значительные нарушения международного права проходило одновременно с отказом от иммунитетов за такие нарушения $^{22}$. По сути, совершение межлународных преступлений было бы невозможно, если бы не участие лиц, занимающих высокие посты, т.к. именно они разрабатывают планы и отдают приказы, поэтому такие лица должны нести бульшую ответственность, чем подчиненные, которые непосредственно совершили деяние ${ }^{23}$. Было бы парадоксом наказывать только исполнителей, оберегая организаторов от уголовной ответственности ${ }^{24}$.

${ }^{20}$ R. vs. Bartley and the Commissioner of Police for the Metropolis and Others, ex parte Pinochet, R. vs. Evans.., ex parte Pinochet (Pinochet № 3) // ILM. 1999. № 38. P. 581 .

${ }^{21}$ Weiß $W$. Völkerstrafrecht zwischen Weltprinzip und Immunität// Juristische Zeitung. 2002. № 14. S. 697 .

${ }^{22}$ Arrest Warrant-Case. Dissenting Opinion of Judge van den Wyngaert. Para. 27.

${ }^{23}$ CM.: International Law Commission Report, Commentary to Art. 7 of the Draft Code of Crimes Against the Peace and Security of Mankind of 5 July 1996. UN Doc A/51/10 // Yearbook of the International Law Commission. 1996. Vol. II (2).

${ }^{24}$ Gaeta P. Official Capacity and Immunities, in: Cassese A., Gaeta P., Jones J. The Rome Statute of the International Criminal Court: A Commentary. Oxford, 2002. P. 983. 
Приверженность такой позиции продемонстрировала и Комиссия международного права ООН. В статью 7 проекта Кодекса о преступлениях против мира и безопасности человечества 1996 г., который предназначался для регулирования как международного, так и национального преследования международных преступлений, Комиссия включила следующую формулу: «Должность индивида, который совершил преступление против мира и безопасности человечества, даже если он действовал как глава государства или правительства, не освобождает его от уголовной ответственности и не смягчает наказание» ${ }^{25}$. В этой формулировке можно рассмотреть обоснование приоритета уголовной ответственности за преступления по общему межлународному праву над иммунитетами как действующих, так и бывших глав государств. Более того, это положение полностью повторяет соответствующие нормы уставов международных трибуналов по бывшей Югославии и по Руацде. В составленном комиссией комментарии к ст. 7 проекта говорится, что «отсутствие процессуальных иммунитетов при осуществлении преследования или наказания. . . является неотъемлемым следствием отсутствия материального иммунитета» ${ }^{26}$, следовательно, можно исходить из того, что Комиссия международного права ООН закрепила в проекте приоритет института уголовной ответственности за преступления по общему международному праву над институтом иммунитетов в международном праве.

Но несмотря на убедительность и логичность приведенных выше аргументов, нельзя забывать, что цель предоставления высшим должностным лицам государства международного иммунитета заключается не только в том, чтобы обеспечить суверенное равенство государств и гарантировать невмешательство одних государств в дела других государств, но и в том, чтобы обеспечить нормальное и эффективное межгосударственное общение. Если представить себе, что национальные суды отдельных государств могли бы без оглядки на иммунитет ratione personae привлекать к уголовной ответственности действующих глав государств, глав правительств, а также министров иностранных дел других государств, то возникла бы ситуация, когда эти лица оказались бы фактически ограничены в передвижении и осуществле-

${ }^{25}$ Draft Code of Crimes Against the Peace and Security of Mankind of 5 July 1996// Yearbook of the International Law Commission. 1996. Vol. II (2).

${ }^{26}$ International Law Commission Report, Commentary to Art. 7 of the Draft Code of Crimes Against the Peace and Security of Mankind of 5 July 1996. UN Doc A/51/10// Yearbook of the International Law Commission. 1996. Vol. II (2). 
нии своих полномочий: перед официальным или частным визитом в какую-либо страну или даже перед каждым транзитом следовало бы вначале, как в шахматной партии, просчитать степень «безопасности» от уголовного преследования и лишь затем отправляться в путь.

Более того, в международньх отношениях редко царит единодушие: одному и тому же событию разные государства дают подчас противоположную оценку. Потому, допусти мы отсутствие иммунитета высших должностных лиц ratione personae, существовала бы возможность для явного злоупотребления правом привлекать к ответственности высокопоставленных представителей других государств. Отсюда следует, что привлечение к уголовной ответственности действующих высших должностных лиц государства, по крайней мере на данном этапе развития международного сообшества, нарушило бы существуюшую стабильность в международных отношениях государств. Потому будет справедливым признать действие международных иммунитетов ratione personae в отношении этой категории лиц даже в том случае, если они обвиняются в совершении международных преступлений. В то же время все вышеперечисленное ни в коей мере не относится к привлечению к ответственности бывших высокопоставленных должностных лиц: предоставление им международного иммунитета вовсе не отвечает указанным целям этого института. Из этого следует, что ответственность таких лиц за международные преступления должна налагаться несмотря на иммунитет ratione materiae.

Такая позиция нашла отражение и в составленной в 2001 г. Институтом международного права резолюции под названием «Иммунитеты глав государств и правительств от юрисдикции и исполнения решений в международном праве» ${ }^{27}$. В этой резолюции зафиксировано, что главы государств и правительств обладают неприкосновенностью и иммунитетом от уголовного преследования независимо от тяжести преступления, которое они могли совершить, в то время как бывшие главы государств и правительств не пользуются иммунитетом от уголовной юрисдикции иностранных судов в случае, если им инкриминируется совершение международных преступлений ${ }^{28}$.

${ }^{27}$ Institut de Droit International, Resolution on Immunities from Jurisdiction and Execution of Heads of State and of Government in International Law of 26 August 2001, http://www.idiiil.org/idiE/resolutionsE/2001_van_02_en.PDF.

${ }^{28}$ Art. 1, 2, 13, 15, 16 of the Resolution on Immunities from Jurisdiction and Execution of Heads of State and of Government in International Law. Cм. также: Fox H. The Resolution of the Institute of International Law on the Immunities of Heads of State and Government // International Criminal Law Quarterly. 2002. P. 120-121. 
Но это только лишь логические умозаключения и проекты, в то время как международное право было и остается во многом прагматическим правом lex lata вместо ожидаемого lex ferenda. И данный случай не исключение: установить приоритет принципа индивидуальной уголовной ответственности за международные преступления над иммунитетом ratione materiae и ratione personae можно только тогда, когда это правило можно будет обнаружить в каком-либо источнике международного права.

\section{3. Международные договоры}

В поисках норм о соотношении международных иммунитетов и уголовного преследования преступлений по общему международному праву обратимся сначала к текстам договорных источников международного права. Договоры по международному гуманитарному праву, которые вводят уголовную ответственность индивидов за военные преступления ${ }^{29}$, не содержат ни одного упоминания об иммунитетах высших должностных лиц государств. В Конвенции против пыток и других жестоких, бесчеловечных или унижающих достоинство видов обращения и наказания также не содержится такой нормы ${ }^{30}$. Конвенция о предупреждении преступления геноцида и наказании за него, напротив, содержит в ст. IV недвусмысленное предписание о том, что виновные «подлежат наказаниюо независимо от того, являются ли они ответственными по конституции правителями, должностными лицами или частными гражданами»; однако в ст. VI сфера действия конвенции ограничивается тем государством, на территории которого было совершено преступление, или международным судом ${ }^{31}$.

\footnotetext{
${ }^{29}$ Женевская Конвенция об улучшении участи раненых и больных в действующих армиях от 12 августа 1949 г.; Женевская Конвенция об улучшении участи раненых, больных и лиц, потерпевших кораблекрушение, из состава вооруженных сил на море от 12 августа 1949 г.; Женевская Конвенция об обращении с военнопленными от 12 августа 1949 г.; Женевская Конвенция о защите гражданского населения во время войны от 12 августа 1949 г.; Дополнительный протокол кЖеневским конвенциям от 12 августа 1949 г., касающийся защиты жертв международных вооруженных конфликтов от 8 июня 1977 г. // Действующее международное право. М., 1999. В 3 т. Т. 2. С. 603, $625,634,681,731$.

${ }^{30}$ Конвенция против пыток и других жестоких, бесчеловечных или унижающих достоинство видов обращения и наказания от 10 декабря 1984 г. //Ведомости Верховного Совета СССР. 1987. № 45.

${ }^{31}$ Конвенция о предупреждении преступления геноцида и наказании за него от 9 декабря 1948 г. // Ведомости Верховного Совета СССР. 1954. № 12.
} 
Таким образом, вряд ли можно говорить о том, что эта конвенция установила правило, которое было бы применимо к преследованию высших должностных лиц государства иностранными судами. Конвенция о пресечении преступления апартеида и наказании за него ${ }^{32}$ не содержит прямого указания на значение иммунитетов, но содержащееся в ст. ІІІ конвенции положение о том, что «международной уголовной ответственности... подлежат лица, члены организаций и учреждений и представители государств», позволяет сделать вывод о том, что международные иммунитеты не должны действовать.

В Римском статуте, учредившем Международный уголовный суд для преследования преступлений против человечности, геноцида, военньх преступлений и преступления агрессии, впервые был закреплен принцип о нераспространении на высших должностных лиц иммунитетов как по национальному, так и по международному праву. Здесь возникает вопрос: действует ли эта норма только тогда, когда преследование осуществляется Международным уголовным судом, т.е. в «вертикальных отношениях», или же государства - участники Римского статута также должны или могут, приняв соответствующее законодательство, ссьлаться на это положение при осуществлении уголовного преследования на национальном уровне, т.е. в «горизонтальных отношениях»?

Существует точка зрения, согласно которой, поскольку по Римскому статуту на основании принципа комплиментарности приоритет в деле преследования международных преступлений отдается национальным судам и, как следствие, именно они «вынуждены» вводить уголовную ответственность за эти составы и преследовать виновных, государства-участники также могут действовать без оглядки на международные иммунитеты ${ }^{33}$. Другая точка зрения базируется на буквальном толковании ст. 27 и ст. 98 статута, в соответствии с которыми иммунитеты не действуют только в рамках преследования, осуществляемого Международным уголовным судом ${ }^{34}$. Получастся, что не исключена ситуация, когда государства - участники статута не смогут привлечь к ответственности высшее должностное лицо, подозреваемое в совершении преступления по общему международному праву,

${ }^{32}$ Международная Конвенция «О пресечении преступления апартеида и наказании за него» от 30 ноября 1973 г. // Сборник действующих договоров, соглашений и конвенций, заклоченных с иностранными государствами. М., 1978. Вып. XXXII. С. 58.

${ }^{33}$ Kleffner J.K. The Impact of Complementarity on National Implementations of Substantive International Criminal Law// Journal of International Criminal Justice. 2003. № 1. P. 103-106.

${ }^{34}$ Triffterer O. Op.cit. P. 509; Gaeta P. Op.cit. P. 996. 
но тогда в дело вступит Международный уголовный суд. Большинство ученых придерживаются именно такой интерпретации Римского статута, считая, что только она соответствует международному обычному праву ${ }^{35}$.

Некоторые государства уже приняли правовые акты по имплементации Римского статута, и можно проследить, каким образом в них урегулирован вопрос о действии иммунитетов. Нидерланды прямо закрепили действие иммунитета ratione personae ${ }^{36}$, а Великобритания закрепила правило о том, что международыые иммунитеты не должны препятствовать осуществлению уголовного преследования международных преступлений ${ }^{37}$. Однако болышинство государств решили не затрагивать этот вопрос в соответствующих актах ${ }^{38}$. Таким образом, государства - участники Римского статута, которые уже имплементировали этот международный договор, заняли сдержанную позицию в отношении отказа от действия иммунитетов при осуществлении преследования международных преступлений.

\section{4. Международный обычай}

Наряду с договором, источником международного права является и международный обычай как «доказательство всеобщей практики, признанной в качестве правовой нормы» ${ }^{39}$. В данном случае для установления существования практики государств и оpinio juris следует проанализировать решения национальных судов, привлекавших к ответственности иностранньх должностньх лиц соответствующего ранга за преступления по общему международному праву. Несомненно, самым важным прецедентом в этой связи являются решения по делу Аугусто Пиночета.

В связи с тем, что в Чили Пиночету был гарантирован «пожизненный иммунитет», возбуждение уголовного дела в отношении бывшего диктатора было возможно только в другом государстве. Таким госу-

${ }^{35}$ Cassese $A$. The Belgian Court of Cassation v. the International Court of Justice: the Sharon and others Case // Journal of International Criminal Justice. 2003. № 1. P. 443.

${ }^{36} \mathrm{Sec} .16$ of the (Dutch) International Crimes Act // http://www.iccnow.org/resourcestools/ ratimptoolkit/nationalregionaltools/legislationdebates/NL.IntCrAct.pdf.

${ }^{37} \mathrm{Sec} .23 \mathrm{Abs} .1$ of the (UK) International Criminal Court Act $2001 / / \mathrm{http}$ :/www.iccnow.org/ resourcestools/ratimptoolkit/nationalregionaltools/legislationdebates/UK.iccAct.2001.pdf. ${ }^{38}$ К примеру, Австрия, Германия, Канада, Словения, Франция, Швейцария, ЮАР.

${ }^{39}$ П. «b» ч. 1 ст. 38 Статута Международного суда ООН от 26 июня 1945 г. // Действующее международноеправо/Сост. Ю.М. Колосов, Э.С. Кривчикова. В 3 т. М., 1999. T. 1.C. 797. 
дарством стала Испания, где было инициировано уголовное преследование Пиночета по обвинению в убийстве испанских граждан в Чили и был выдан международный ордер на арест. На основании этого ордера в 1998 г. бывший диктатор был арестован лондонской полицией. Началась подготовка к выдаче Пиночета Испании на основании Европейской конвенции об экстрадиции, однако адвокаты Пиночета подали в суд обращение habeas corpus. В первом решении, вынесенном Апелляционным присутствием отделения королевской скамьи, требования Пиночета были удовлетворены: было признано, что он обладает иммунитетом. Так дело попало в высшую судебную инстанцию Соединенного Королевства - Палату лордов. К тому времени в отношении генерала было выдвинуто другое обвинение: в пытках и захвате заложников.

Судьи Палаты лордов пришли к выводу, что Пиночет не обладает иммунитетом в отношении преступлений, совершенных им во время пребывания в должности президента. В решении было указано, что преступления, в совершении которых обвиняется генерал, не могут рассматриваться как официальные действия: «Международное право сделало очевидным, что определенные виды деяний, включая пытки и взятие заложников, являются неприемлемыми, кем бы они ни совершались. Это применимо к главам государств так же, и даже больше, чем к кому-либо другому; противоположный вывод был бы насмешкой над международным правом» ${ }^{40}$. Это решение было оспорено адвокатами Пиночета на основании того, что один из судей-лорд Хоффман - был заинтересован в исходе дела. В связи с нарушением принципа независимости первое решение Палаты лордов по делу Пиночета было отменено.

Третий процесс в Палате лордов проходил уже при другом составе судей, и, хотя и с иной аргументацией, суд решил, что Пиночет не обладает иммунитетом от уголовного преследования. При этом суд вынес достаточно «консервативное» решение: посчитав, что отсутствуют соответствующие нормы обычного права, он сослался только на договорные нормы международного права, а именно на Конвенцию против пыток 1984 г. Эта конвенция была ратифицирована Соединенным Королевством только в конце 1988 г., поэтому - сочли судьи - она

${ }^{40}$ R.vs. Bartle and the Commissioner of Police for the Metropolis and Others, ex parte Pinochet, R. vs. Evans... ex parte Pinochet. House of Lords, 25 November 1998 (Pinochet № 1) // ILM. 1998. № 37. P. 1302. 
была применима только к тем деяниям, которые были совершены Пиночетом в последние пятнадцать месяцев его правления, при том что большинство преступлений, в которых обвинялся генерал, были совершены в течение первых четырех месяцев после вооруженного переворота. Захват заложников - другой состав преступлений, который инкриминировался генералу, - по мнению Палатылордов, не подпадал под действие акта о захвате заложников $1982 ~ г{ }_{.}^{41}$ Однако по состоянию здоровья Пиночет так и не был выдан Испании, и ему разрешили вернуться в Чили.

Несмотря на то, что процесс в Испании так и не состоялся и диктатор не был осужден, это дело представляет собой самый первый случай, когда бывший глава государства предстал перед национальным судом другого государства и рассматривалось дело о нарушении международного права. Более того, первый раз было признано, что бывший глава иностранного государства не обладает иммунитетом ratione materiae в отношении деяний, запрещенных международным правом.

Не вдаваясь глубоко в анализ этих решений, отметим, что Палата лордов ни в первом, ни в третьем решении не стала уточнять, что произошло с традиционной доктриной иммунитетов глав государств и окончательно ли ее сменили обычные нормы международного права, вводящие новую, более ограниченную концепцию, отрицающую иммунитет в случае совершения международных преступлений. Однако решение Палаты лордов по делу Пиночета имело для международного права непреходящее значение: оно стало отправной точкой для возбуждения уголовных дел в других государствах, и все последующие попытки привлечь высокопоставленных должностных лиц к ответственности так или иначе базировались на этом решении ${ }^{42}$. В различных государствах были инициированы процессы против бывших и действующих глав других государств по обвинению в совершении международных преступлений. Так, суд первой инстанции Сенегала вынес обвинительное заключение в отношении Хиссена Хабре - бывшего диктатора Чад, управлявшего страной с 1982 по 1990 г. Однако процесс был прекращен на основании решений вышестоящих судов, которые установили, что они не обладают юрисдикцией рассматри-

${ }^{41}$ R. vs. Bartley and the Commissioner of Police for the Metropolis and Others, ex parte Pinochet, R. vs. Evans.., ex parte Pinochet (Pinochet № 3)// ILM. 1999. № 38. P. 581 .

${ }^{42}$ Sears J.M. Confronting the «Culture of Impunity»: Immunity of Heads of State from Nuremberg to ex parte Pinochet//German Yearbook of International Law. 2000. P. 146. 
вать такое дело ${ }^{43}$. На данный момент в отношении Хабре возбуждено уголовное дело в Бельгии.

Тем не менее далеко не во всех случаях бывшие главы государств привлекаются к уголовной ответственности в иностранных государствах. Ярким примером тому служит ситуация с бывшим перуанским президентом Альберто Фухимори, который вовремя нашел прибежище в Японии. В самом Перу против бывшего главы государства были выдвинуты многочисленныс обвинения. Япония, в свою очередь, признала, что Фухимори обладает гражданством Японии, а граждане Японии не подлежат выдаче другим государствам. Казалось бы, в свете развития международного уголовного права в Японии и должен был состояться процесс над бывшим президентом, однако уголовное дело против Фухимори так и не было возбуждено ${ }^{44}$.

Среди процессов над действующими главами государств, инициированных в иностранных государствах, можно в качестве примера отметить процессы над Муаммаром аль Каддафи и Ариэлем Шароном. Так, с октября 1999 г. по март 2001 г. во Франции длился судебный процесс в отношении ливийского лидера Муаммара аль Каддафи. К тому времени Каддафи фактически оставался действующим главой государства, хотя и сменил свой пост президента Общего Народного Конгресса на звание «лидера великой революции 1 сентября». После начала процесса в суде первой инстанции прокурор подал жалобу в апелляционный суд, ссылаясь на то, что Каддафи обладает иммунитетом и, следовательно, не подлежит уголовному преследованию. Апелляционный суд в своем решении от 20 октября 2000 г. пришел к выводу, что лица, обвиняемые в совершении международных преступлений, не пользуются международным иммунитетом. Однако Верховньй суд Франции отменил это решение на основании того, что, каким бы серьезным ни было нарушение международного права, нельзя делать исключения из иммунитета действующего главы государства.

В 2001 г. по заявлению ливанцев и палестинцев в Бельгии было начато уголовное расследование в отношении Ариэля Шарона по делу о преступлениях, совершенных в 1982 г. в городах Сабре и Шатиле,

${ }^{43}$ Ruffert M. Pinochet follow up // Netherlands Journal of International Law. 2001. Vol. 48. № 2. P. 174-175.

${ }^{44}$ Anderson K. An Asian Pinochet?-Not Likely: The Unfulfilled International Law Promise in Japan's Treatment of Former Peruvian President Alberto Fujimori// Stanford Journal of International Law. 2002. № 38. P. 180-181, 196-198. 
когда подозреваемый занимал пост министра обороны ${ }^{45}$. Он обвинялся в геноциде, преступлениях против человечности и в военных преступления ${ }^{46}$. Правомерность возбуждения уголовного дела была оспорена прокурором в суде апелляционной инстанции. И если этот суд признал такой процесс незаконным, сославшись на то, что обвиняемый должен присутствовать на территории Бельгии, то Верховный суд Бельгии признал, что уголовное преследование А. Шарона неправомерно, так как он на момент подачи частными лицами заявления и на момент принятия судом решения является действуюшим премьерминистром иностранного государства и, следовательно, пользуется иммунитетом от уголовного преследования ${ }^{47}$.

Таким образом, вплоть до настоящего момента в истории еще не было случаев привлечения к уголовной ответственности действующего главы государства или других высокопоставленных должностных лиц за преступления по общему международному праву иностранными судами.

Отсутствие договорных норм, равно как и практики привлечения к ответственности действующих руководителей государства на национальном уровне, позволяет согласиться с выводами Международного суда ООН только в той части, что в международном праве не сложилось международного обычая о приоритете индивидуальной ответственности высших должностных лиц государства за преступления по общему международному праву над международными иммунитетами ratione personae в случае, когда преследование происходит на национальном уровне. Вместе с тем современное международное право исходит из правомерности преследования национальными судами бывших высокопоставленных должностных лиц иностранных государств, т.е. свою силу утратил иммунитет ratione materiae.

В итоге можно сделать вывод о том, что соотношение принципа индивидуальной уголовной ответственности и международных иммунитетов меняется в зависимости от того, какие суды: национальные или международные - осуществляют уголовное преследование. Но сложившаяся разница между национальным и межлународным

${ }^{45}$ CM.: Altman H. The Future of the Head of State Immunity: The Case against Ariel Sharon, http://www.indictsharon.net/heidialtman-apr02.pdf.

${ }^{46}$ Cassese A. Указ. соч. С. 438.

${ }^{47}$ Решения Cour d'appel от 26 июня 2002 г. и Cour de Cassation от 12 февраля 2003 г. доступны в Интернете по адресу: http://www. Sabra-shatila.be/documents/ arrest020226.pdf; http://www.cass.be/cgi-juris/juris-cass-al.pl. 
уровнями преследования является, по сути, самым оптимальным вариантом баланса между императивом индивидуальной уголовной ответственности за самые серьезные нарушения международного права, с одной стороны, и принципами суверенного равенства государств, невмешательства и эффективного функционирования государства - с другой.

Однако нельзя не отметить, что такое положение вещей пронизано неким лукавством: получается, что высокопоставленный государственный деятель все же может скрыться за своей должностыю и протянуть время до того момента, когда он - уже старый и больной - вряд ли сможет стать объектом серьезного уголовного разбирательства. Сложившееся положение потенциально может изменить практика государств, ратифицировавших Римский статут, по введению в национальное законодательство норм о нераспространении иммунитетов на высшие должностные лица государств при осуществлении уголовного преследования за международные преступления. Но до сих пор такая тенденция еще не наметилась.

И все же нельзя говорить о полной безнаказанности высокопоставленных преступников, потому как принцип индивидуальной уголовной ответственности имеет приоритет перед международными иммунитетами при осуществлении преследования на международном уровне, а на национальном уровне утратили свою силу материальные иммунитеты бывших руководителей государств. И в этом - послание современного международного права высокопоставленным должностным лицам: «Иммунитет не может защищать вечно!» 